\title{
Nitrogen use on Canterbury dryland pastures
}

\author{
J.D. MORTON' and S.D. MCBRIDE ${ }^{2}$ \\ ${ }^{1}$ AgResearch, Invermay Agricultural Centre, PB S0034, Mosgiel \\ ${ }^{2}$ AgResearch, Winchmore Research Station, PB, Ashburton
}

\section{Abstract}

Results from the first two years of a farmlet trial carried out on a dryland Lismore soil near Ashburton, Mid Canterbury are reported. Farmlet treatments were $0,25(25 \mathrm{~N})$ and $50(50 \mathrm{~N}) \mathrm{kg}$ $\mathrm{N} /$ ha applied as urea in mid-April of 1992 and 1993. Stocking rates for each farmlet were 9.5 , 10.5 and 11.5 (Year 1), and 11, 12 and 13/ha Borderdale ewes/ha (Year 2). For both years of the trial, there were small increases in mean pasture cover from $\mathrm{N}$ use despite the higher stocking rates on the $\mathrm{N}$ farmlets. Both mean clover content $(14 \%)$ and $\mathrm{N}$ fixation rates $(36 \mathrm{~kg}$ N/ha/year) were low but only declined slightly with $\mathrm{N}$ use. Average lamb carcass weight was lower on the $25 \mathrm{~N}$ and $50 \mathrm{~N}$ farmlet than the nil $\mathrm{N}$ farmlet $(16.9 \mathrm{cf} 18.3 \mathrm{~kg})$. Despite this decrease, lamb carcass production per ha was significantly higher on the $50 \mathrm{~N}$ farmlet $(216 \mathrm{~kg} / \mathrm{ha})$ compared with the nil $\mathrm{N}$ farmlet $(199 \mathrm{~kg} / \mathrm{ha})$, Similar wool weights per ewe between farmlets resulted in an increase in wool production per ha from both $\mathrm{N}$ farmlets $(25 \mathrm{~N}=34.9 \mathrm{~kg} / \mathrm{ha}, 50 \mathrm{~N}=38 \mathrm{~kg} / \mathrm{ha})$ compared to nil $\mathrm{N}(30.8 \mathrm{~kg} / \mathrm{ha})$.

Keywords: clover content, lamb production, nitrogen fertiliser, nitrogen fixation, stocking rate, wool production

\section{Introduction}

Nitrogen (N) fertiliser use on New Zealand pastures has increased rapidly since the 1970s. Most $\mathrm{N}$ fertiliser has been used on intensive dairy and beef farms under adequate rainfall. Farmlet research carried out at Ballatitrae (Clark \& Lambert-1989) -and Lincoln (Hoglund \& Pennell 1989) has shown increases in sheep production from use of $\mathrm{N}$ fertiliser. A recent survey of east coast dryland sheep and beef farms found that $\mathrm{N}$ use was associated with increases in animal and financial performance (Morton et al. 1993). Since N supply to pastures could be limited by lack of legume growth in dryland areas it was considered that there could be benefits from the use of $\mathrm{N}$ fertiliser. Apart from the Lincoln farmlet trial, there has been no research on $\mathrm{N}$ use under dryland conditions. Therefore a farmlet trial was established on a Lismore soil at Winchmore
Research Station to investigate responses to $\mathrm{N}$ fertiliser under sheep grazing. This paper will report the first two years' results from this trial.

\section{M ethods}

\section{Site and treatments}

In summer 1991/92, three 5.2 ha farmlets were established on Lismore silt loam at Winchmore Research Station near Ashburton (long-term average annual rainfall $738 \mathrm{~mm}$ ). The pasture mix sown in each farmlet consisted of $53 \%$ of the area with 2- to 3year-old ryegrass (Lolium perenne -seed harvested from Winchmore demonstration farmlet $\mathrm{S}$ block)/Grasslands Huia white clover, $37 \%$ of the area with Grasslands Wana cocksfoot (Dactylis glomerata)/Grasslands Maru phalaris (Phalaris aquatica)/Huia white clover (Trifolium repens)/Mt Barker subterranean clover (Trifolium subterraneum) and $10 \%$ of the area with 2 . year-old Wairau lucerne (Medicago sativa). Each farmlet was subdivided into 130.4 ha paddocks. Soil nutrient status of the site was high (mean Olsen $\mathrm{P}=30$, $\mathrm{SO},-\mathrm{S}=12$ ) as was the soil $\mathrm{pH}$ (mean 6.0). In mid April 1992 and 1993, 0,25 and $50 \mathrm{~kg} \mathrm{~N} / \mathrm{ha}$ was applied as urea to each farmlet on all pasture types except lucerne.

\section{Management}

The trial was stocked with mixed-age Borderdale ewes. In the first year (1992/93) the different stocking rates for the $\mathbf{0 , 2 5}$ and $50 \mathrm{~kg} \mathrm{~N} / \mathrm{ha}$ farmlets were $9.5,10.5$ and 11.5 SU/ha respectively. These stocking rates were increased to 11, 12 and 13 SU/ha in the second year (1993/94) so that potential extra pasture growth from N could be more fully utilised and more grazing pressure was placed on the nil $\mathrm{N}$ treatment. Progressively higher stocking rates were-used on the two $\mathrm{N}$ farmlets because other workers (Clark \& Lambert 1989; Hoglund \& Pennell 1989) could not achieve significant increases in individual animal performance from $\mathrm{N}$ use at the same stocking rate. Therefore the treatment effects presented are $\mathrm{N}$ fertiliser $\mathrm{x}$ stocking rate effects. The ewes lambed in early to mid August and weaning was in November. Lamb numbers were adjusted so that there were similar differences between farmlets as for ewes. Cull ewes were replaced in March by purchased 2 th ewes. Each farmlet group of ewes and weaned lambs was rotated in separate mobs. The lamb selling policy was set so that 
all lambs were sold at a time to ensure that average ewe liveweight never dropped below $50 \mathrm{~kg}$. Since ewe liveweight remained above this level for the first two years of the trial, lambs were sold by the end of March to ensure that there was adequate pasture cover for ewe feed requirements during winter.

\section{Measurements}

Pasture: Pasture cover on each paddock was estimated weekly from measurements of pre- and post-grazing pasture mass. Each month, herbage samples were dissected for \% sown grass and legume. $\mathrm{N}$ fixation was measured every 3 weeks using the acetylene reduction technique (Hoglund \& Brock 1978).

Animal: Both lambs and ewes were weighed monthly and fleece weight measured at each shearing. The carcass weight of each lamb was also recorded.

\section{Statisticalanalysis}

For the pasture measurements, paddocks within each farmlet were used as replicates in the analysis of variance. Weekly pasture cover measurements were converted to smoothed curves (Figure 1) using the statistical package "Flexi". Since there was only one group of ewes or lambs in each farmlet, individual animals were used as experimental units in the analysis of variance of animal measurements.

Figure 1 Mean farmlet pasture cover.

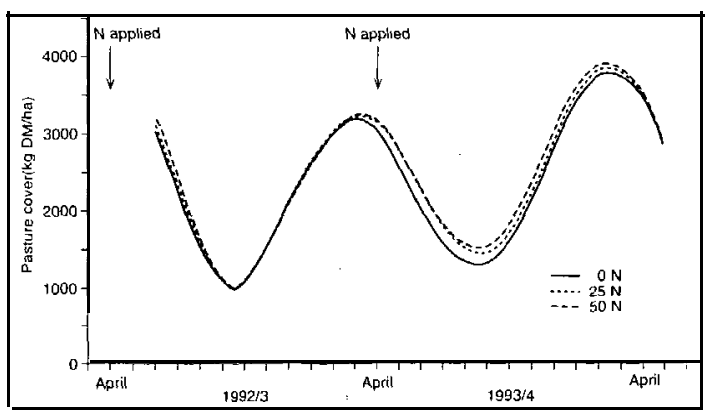

\section{Results and discussion}

Trial results associated with pasture measurements are presented for both years while those associated with lamb carcass weight and ewe wool weight are presented as means over 2 years. This difference in presentation is due to the greater variation between years for pasture compared to animal measurements. In this section the $25 \mathrm{~kg} \mathrm{~N} / \mathrm{ha}$ farmlet will be referred to as $25 \mathrm{~N}$ and the $50 \mathrm{~kg} \mathrm{~N} / \mathrm{ha}$ farmlet as $50 \mathrm{~N}$.

\section{Pasture cover}

Although there were only small increases in annual mean pasture cover on the $2.5 \mathrm{~N}$ and $50 \mathrm{~N}$ farmlets compared with nil $\mathrm{N}$ (Table 1), the maintenance of higher stocking rates on the $\mathrm{N}$ farmlets suggested that there were pasture yield responses to $\mathrm{N}$. In Year 2, despite higher stocking rates, use of $\mathrm{N}$ resulted in a slightly greater increase in pasture cover than Year 1. The difference in pasture cover between the nil $\mathrm{N}$ and $\mathrm{N}$ farmlets increased from mid-April to mid-September but diminished thereafter (Figure 1). The lower pasture cover from $\mathrm{N}$ use in Year 1 compared with Year 2 could have been due to much lower rainfall from January to April (130 cf $300 \mathrm{~mm})$ followed by lower daily soil temperatures (5.4 cf 6.2 " $\mathrm{C}$ ) from April to September.

\section{Clover content and $\mathrm{N}$ fixation}

Clover content showed a trend for a slight decline with increasing rate of $\mathrm{N}$ fertiliser (Table 2). This small decrease was similar to that reported by Clark \& Lambert (1989) and was a result of stocking rate being sufficient to limit the shading of clovers by grasses.

There was a trend (non significant) for $\mathrm{N}$ fixation rate to decline with $\mathrm{N}$ fertiliser application (Table 2). The relatively low $\mathrm{N}$ rates used in this trial would not be expected to affect $\mathrm{N}$ fixation rate to the same extent as measured at higher rates of $\mathrm{N}$ (Ball $\boldsymbol{e t}$ al. 1978). Absolute rates of $\mathrm{N}$ fixation were lower than

Table 1 Mean pasture cover (kg DM/ha) for each fannlet.

\begin{tabular}{lcccc}
\hline & \multicolumn{3}{c}{ Rate of N (kg/ha/yr) } & LSD(5\%) \\
& 0 & 25 & 50 & \\
\hline Year 1 & 2540 & 2560 & 2570 & 75 \\
Year 2 & 2550 & 2660 & 2710 & 135 \\
Mean & 2545 & 2610 & 2640 & 75 \\
\hline
\end{tabular}

Table 2 Clover content $(\%)$ and $\mathrm{N}$ fixation rate $(\mathrm{kg} \mathrm{N} / \mathrm{ha} / \mathrm{yr})$ for each farmlet.

\begin{tabular}{lcccc}
\hline & \multicolumn{2}{c}{ Rate of N (kg/ha/yr) } & LSD $(5 \%)$ \\
& 0 & 25 & 50 & \\
\hline Clover content & & & & \\
Year 1 & 15.7 & 14.2 & 13.9 & 2.4 \\
Year 2 & 13.7 & 11.9 & 12.1 & 2.7 \\
Mean & 14.7 & 13.1 & 13.0 & 1.6 \\
N fixation rate & & & & \\
Year 1 & 60 & 47 & 40 & 18 \\
Year 2 & 24 & 21 & 18 & 18 \\
Mean & 42 & 34 & 33 & 11 \\
\hline
\end{tabular}


the average rate of $126 \mathrm{~kg} \mathrm{~N} / \mathrm{ha} / \mathrm{yr}$ measured under dryland pasture in Central Canterbury (Crush 1979). However the index of $\mathrm{N}$ fixed/clover content was similar for both trials. The much lower rate of $\mathrm{N}$ fixation in Year 2 compared with Year 1 was due to a large decrease in clover content in the predominantly cocksfoot paddocks.

\section{Ewe liveweight}

There was a significant difference in ewe liveweight between the nil and $25 \mathrm{~N}$ farmlets at weaning in Year 2 only but small significant differences between nil and $50 \mathrm{~N}$ occurred at pre-mating in both years and prelambing and weaning in Year 2 (Table 3). Clark \& Lambert (1989) reported no significant effect of $\mathrm{N}$ on ewe liveweight while Hoglund \& Pennell (1989) measured significantly higher pre-lambing ewe liveweights from $\mathrm{N}$ use. The decline in ewe liveweight in the reported trial was presumably due to the higher stocking rate on the $50 \mathrm{~N}$ farmlet not being completely sustained by the extra pasture grown.

\section{Lamb production}

Although lamb carcass weight was significantly greater $(\mathrm{P}<0.05)$ for the nil $\mathrm{N}$ compared with the $25 \mathrm{~N}$ and 50 $\mathrm{N}$ farmlets, the greater numbers of lambs carried on the $50 \mathrm{~N}$ farmlet resulted in significantly higher lamb production per ha (Table 4). On the $25 \mathrm{~N}$ farmlet, the decrease in lamb carcass weight from nil $\mathrm{N}$ was not compensated for by the higher number of lambs sold.

At a similar differential-in stocking-rate-per-rate-of- $\mathrm{N}$ applied (1 ewe per $25 \mathrm{~kg} \mathrm{~N} / \mathrm{ha}$ ), Hoglund \& Pennell (1979) reported similar lamb carcass weight and higher carcass weight per ha. Clark \& Lambert (1989) found that lamb production per ha significantly increased from application of 37 and $50 \mathrm{~kg} \mathrm{~N} / \mathrm{ha}$.

\section{W ool production}

In contrast to lamb carcass weight, wool production per ewe was similar across all farmlets (Table 5). As a result, wool productionper ha increased significantly with rate of $\mathrm{N}$. This increase in wool production per ha was consistent with results from Clark \& Lambert (1989) and Hoglund \& Pennell (1989).

\section{E conomics}

After 2 years of the planned 4-year duration of the trial, financial returns from lamb and wool production exceeded the cost of the $\mathrm{N}$ fertiliser on the $50 \mathrm{~N}$ farmlet (\$64 return cf $\$ 50$ cost) but not on the $25 \mathrm{~N}$ farmlet
Table 3 Ewe liveweight $(\mathrm{kg})$ at pre-lambing, weaning and premating for each farmlet.

\begin{tabular}{lcccc}
\hline Date & \multicolumn{3}{c}{ Rate of N (kg/ha/yr) } & LSD (5\%) \\
& 0 & 25 & 50 & \\
\hline August 1992 & 55.1 & 56.5 & 54.3 & 2.2 \\
November 1992 & 60.7 & 60.2 & 50.7 & 2.7 \\
February 1993 & 61.1 & 58.9 & 56.9 & 2.8 \\
August 1993 & 63.2 & 61.5 & 60.0 & 2.9 \\
October 1993 & 62.9 & 58.8 & 58.0 & 3.1 \\
March 1994 & 61.9 & 59.3 & 57.5 & 3.6 \\
\hline
\end{tabular}

Table 4 Lamb carcass weight $(\mathbf{k g} / \mathbf{h d})$ and lamb production $(\mathrm{kg} / \mathrm{ha})$ from each farmlet (mean of 2 years).

\begin{tabular}{lcc}
\hline Rate of $N$ & $\begin{array}{c}\text { Lamb carcass } \\
\text { weight } \mathbf{( k g / h d )}\end{array}$ & $\begin{array}{c}\text { Lamb production } \\
\mathbf{( k g / h a )}\end{array}$ \\
\hline 0 & 18.3 & 199 \\
25 & 16.9 & 200 \\
50 & 16.9 & 216 \\
L S D (5\%) & 0.5 & 5.7 \\
\hline
\end{tabular}

Table 5 Wool production (kg/ewe and $\mathrm{kg} / \mathrm{ha}$ ) from each farmlet (mean of 2 years).

\begin{tabular}{ccc}
\hline Rate of $N$ & \multicolumn{2}{c}{ Wool production } \\
& $\mathrm{kg} / \mathrm{ewe}$ & $\mathrm{kg} / \mathrm{ha}$ \\
\hline 0 & 3.0 & 30.8 \\
25 & 3.1 & 34.9 \\
50 & 3.1 & 38.0 \\
LSD (5\%) & 0.15 & 1.69 \\
\hline
\end{tabular}

( $\$ 17$ return cf $\$ 25$ cost). The values used in this simple analysis were $\$ 2.50 / \mathbf{k g}$ lamb carcass weight, $\$ 4 / \mathrm{kg}$ wool and $\$ 1 / \mathrm{kg} \mathrm{N}$ applied. The lack of economic response at $25 \mathrm{~kg} \mathrm{~N} / \mathrm{ha}$ was due to the lower lamb carcass weight. The marginal economic performance from $\mathrm{N}$ use so far should be considered in the light of a lower pasture response in a year (1992/93) with dry late summer/autumn and cold winter/early spring climatic conditions. Nevertheless the result highlights the risk of not gaining an economic return to $\mathrm{N}$ insuch conditions. Regular $\mathrm{N}$ use over a longer period would be expected to discount the results from poor climatic years.

\section{Conclusions}

$\mathrm{N}$ fertiliser use on a dryland Canterbury site maintained higher stocking rates for the first two years of a farmlet trial. Application of $\mathrm{N}$ at 25 and $50 \mathrm{~kg} / \mathrm{ha}$ had little effect on clover content and $\mathrm{N}$ fixation rate. Lamb 
carcass weight declined with $\mathrm{N}$ use and increased stocking rate but there was a significant increase in lamb carcass production per hectare at $50 \mathrm{~kg} \mathrm{~N} / \mathrm{ha}$. Wool production per ewe was similar for all $\mathrm{N}$ farmlets resulting in an increase in wool production per hectare from 25 and $50 \mathrm{~kg} \mathrm{~N} / \mathrm{ha}$. Although the financial returns from $\mathrm{N}$ use were disappointing, it should be stressed that responses have only been measured over two years so far, including one year (1992193) with abnormally poor climatic conditions during winter and early spring.

\section{ACKNOWLEDGEMENTS}

The authors wish to thank Gary Green and Joy Talbot for technical assistance and David Baird for statistical analysis.

\section{REFERENCES}

Ball, R.; Molloy, L.F.; Ross, D.J. 1978. Influence of fertiliser nitrogen on herbage dry matter and nitrogen yields and botanical composition of a grazed grass/ clover pasture. New Zealandjournal of agricultural research 21: $47-55$.
Crush, J.R. 1979. Nitrogen fixation in pasture. IX. Canterbury Plains, Kirwee. New Zealand journal of experimental agriculture 7: 3.5-38.

Clark, D.A.; Lambert, M.G. 1989. The use of fertiliser nitrogen for increased animal production from New Zealand hill pastures. Proceedings of the Massey University Workshop Nitrogen in New Zealand Agriculture and Horticulture: 37-41.

Hoglund, J.H.; Brock, J.L. 1978. Regulation of nitrogen fixation in a grazed pasture. New Zealand journal of agricultural research 21: 73-82.

Hoglund, J.H.; Pennell, C.G.L. 1989. Autumn nitrogen fertiliser in a dryland sheep system. Proceedings of the New Zealand Grassland Association 50: 135-138.

Morton, J.D.; Smith, D.R.; Korte, C.J.; Watt, B.D.; Smith, R.G. 1993. Nitrogen use and farm performance on Wairarapa sheep and beef farms. Proceedings of the New Zealand Grassland Association 55: 53-58.

Morton, J.D., Ledgard, SF., O’Connor, M.B. 1993, Nitrogen use in New Zealand farming systems. Proceedings of the New Zealand Fertiliser Manufacturers Research Association: 198-204. 